\title{
Reseña del libro: Cabero, J. y Barroso, J. (coords.) (2015). Nuevos retos en tecnología educativa. Madrid: Síntesis.
}

\author{
Juan Antonio Gutiérrez Gómez \\ Universidad de Murcia \\ juanantonio.gutierrez1@um.es
}

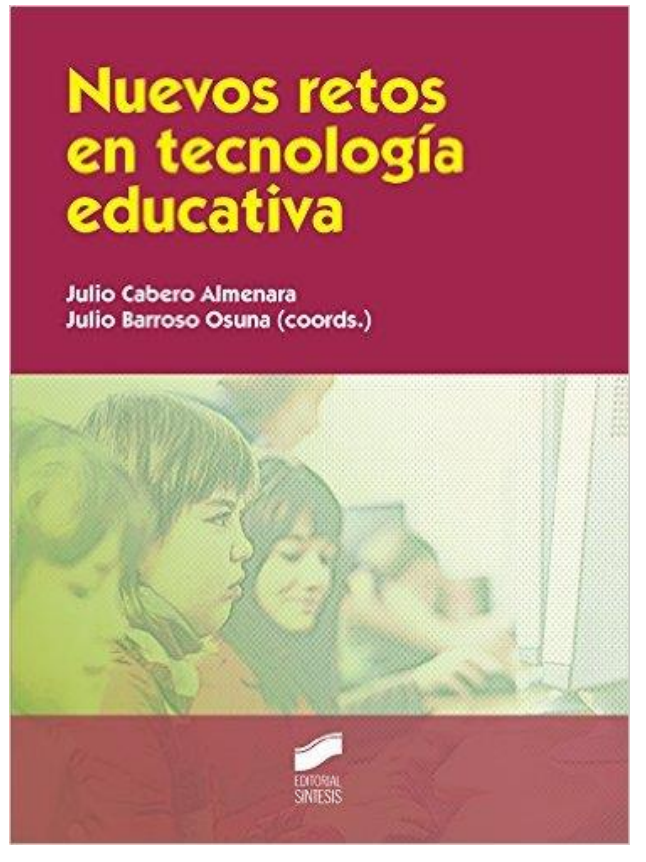

Los cambios que se producen día a día en este mundo globalizado, inserto en lo que se conoce como revolución tecnológica, son numerosos y muy rápidos. Las Tecnologías de la Información y la Comunicación (TIC) revolucionan la sociedad. La educación, como aspecto básico y esencial, también demanda de esas transformaciones para actualizar los planteamientos educativos. Pasamos de modelos tradicionales, a perspectivas innovadoras que presentan una nueva línea para un tiempo nuevo. Una orientación que no es estanca, sino cambiante debido a su necesaria y constante actualización.

A través de este libro se nos introduce en el presente, haciendo un recorrido histórico por los hechos más importantes que han marcado la historia de la tecnología educativa (TE) y su investigación, y se exponen las bases del futuro más inmediato de esta materia. Los autores, apoyados en una ingente fundamentación teórica, comparten una serie de conceptos básicos y actuales, dan respuestas y exponen de forma conexa numerosas teorías, clasificaciones y puntos de vista, así como estudios, investigaciones y análisis, entre otros aspectos, sobre los puntos más candentes y los nuevos retos que se platean en la TE.

Una de las ideas esenciales, que los autores repiten constantemente, es tener claro que la TE es significativa, viva, contradictoria, polisémica e integradora. A pesar de que es un concepto de reciente creación, la rápida evolución a la que está sometida le otorga a estudios, investigaciones, escritos, etc., una necesaria y temprana actualización. Aún así las aportaciones ya realizadas no son trabajo en vano, sino que son paradas imprescindibles en el proceso de la TE, marcado por un carácter significativo.

Precisamente, en este proceso, son imprescindibles una serie de agentes que necesitan renovarse. Los roles cambian, y a lo largo de este libro son numerosas las referencias a este aspecto, en las que se aportan nociones y orientaciones muy interesantes para las comunidades educativas. Los docentes, por ejemplo, pasan de ser instructores a guías del conocimiento. El papel del profesor es clave para realizar cualquier innovación tecnológica. En un contexto interactivo, se convierten en diseñadores, orientadores, consultores de información, evaluadores continuos y seleccionadores de TIC. Y los alumnos, que adquieren un papel más activo, se ven envueltos en nuevas metodologías y formas de trabajo (aprendizaje colaborativo, proyectos de grupo...) que le otorgan a las clases un carácter más motivador y 
tecnológico. Los estudiantes del futuro deberán tener, según los autores, una serie de competencias para aprender conocimientos nuevos, desprender conocimientos adquiridos y ya no válidos por las trasformaciones del mundo científico. $Y$ sobre competencias, subrayar la digital, tan impulsada en el último lustro y recogida en los currículos escolares.

Vivimos en tiempos "líquidos" donde nada es estable, tal y como recogen los autores. Los ordenadores, proyectores... se aproximan, en el corto plazo, a otros recursos como son las aplicaciones y los medios móviles, los contenidos abiertos, la realidad aumentada y los PLE (entornos personales de aprendizaje). En relación a los entornos, considerar los nuevos entre los que destacan: el e-learning (educación a distancia enriquecida con tecnología), el b-learning (similar a la enseñanza semipresencial) y el m-learning (enseñanza mediante aplicaciones móviles). Gracias a este manual podemos responder a preguntas tan necesarias en este tiempo como ¿dónde? y ¿con qué?

Son muchas las tecnologías que se pueden aplicar a la práctica educativa. Hoy en día resulta muy fácil la grabación de vídeos o de audios, por ejemplo. Pulsando un simple botón en el móvil generamos infinidad de contenido multimedia que podemos trabajar y compartir a través de Internet. A lo largo del libro se recogen una serie de enlaces a páginas, en las que poder adentrarnos en la TE como emisores y/o receptores de información y conocimiento. Según los profesionales que participan en el libro, no existen medios mejores que otros, su utilidad depende de la interacción entre variables y de los objetivos que se persiguen.

Los autores plantean que las bondades que presentan las tecnologías por sí solas no las pueden cumplir. Resulta necesario avanzar en la investigación para poder dar respuestas. Es de interés para investigadores conocer las tendencias emergentes en TE, consultadas en diferentes informes y recogidas en este manual, que son nuevas formas de enseñar y aprender aprovechando el potencial de la tecnología. Algunas de ellas son: nuevas pedagogías para libro electrónico (e-book), cursos en línea, abiertos y masivos (MOOC), aula invertida (flipped classroom), juegos y "gamificación", web 2.0, tecnologías móviles, etc. Además se exponen líneas futuras de investigación: el tipo de interacción que el sujeto establece con los nuevos medios interactivos, alfabetización y escolarización a través de nuevos medios, el diseño de medios para la formación continua e individualizada, valores que transmiten los medios, estudios sobre la competencia digital de los alumnos y los profesores, las posibilidades de las herramientas Web 2.0 para la educación, el impacto de las redes sociales y sus posibilidades para la formación de estudiantes, etc.

De forma concluyente señalar que la lectura del libro resulta sencilla y amena. La estructura planteada permite focalizar en los aspectos planteados y conectar las ideas. El texto va acompañado de imágenes, esquemas y otros gráficos que son un gran apoyo a lo escrito. El espíritu entusiasta que transmiten los profesionales que participan en el libro es, sin duda alguna, un gran elemento de enganche para la realización de una lectura esencial en el campo de la innovación en la tecnológica educativa.

\section{(cc) EY-NC}

Los textos publicados en esta revista están sujetos a una licencia de Reconocimiento 4.0 España de Creative Commons. Puede copiarlos, distribuirlos, comunicarlos públicamente y hacer obras derivadas siempre que reconozca los créditos de las obras (autoría, nombre de la revista, institución editora) de la manera especificada por los autores o por la revista. La licencia completa se puede consultar en:Licencia Creative Commons Atribución-NoComercial-Compartir por igual 4.0 Internacional. 